\title{
KAJIAN HUKUM DAMPAK REGULASI PERATURAN MENTERI PERHUBUNGAN TERHADAP MASKAPAI PENERBANGAN BUMN DAN SWASTA
}

\author{
Asmah \\ Universitas Sawerigading Makassar
}

\begin{abstract}
Economic development is strongly supported by transportation tools and facilities and infrastructure and legal progress of a country is the ideals of all nations, which is the main force in encouraging the development of a country, especially Indonesia. As a democracy and a state of law. That the unitary State of the Republic of Indonesia is a archipelagic country characterized by a territorial sea and air territory with boundaries, rights and sovereignty established by law. In the advancement of a country, especially an archipelagic country like Indonesia, transportation is a very important thing to reach each island or region quickly, it certainly requires a government attention and regulation to arrange so that the flight becomes a fun thing for all its users. government through the Minister of Transportation No. 89 of 2015 on the handling of flight delays (Delay) at Niaga Air Transport Agency is scheduled in Indonesia.
\end{abstract}

Keywords :

Impact, Regulation, Airline

\begin{abstract}
Abstrak
Pembangunan bidang ekonomi sangat ditunjang oleh alat trasnportasi dan sarana serta prasarana dan kemajuan hukum suatu negara merupakan cita-cita semua bangsa, yang merupakan kekuatan utama dalam mendorong perkembangan suatu negara, terutama Indonesia. Sebagai negara demokrasi dan negara hukum. Bahwa Negara kesatuan Republik Indonesia adalah Negara kepualauan berciri nusantara yang disatukan oleh wilayah perairan dan udara dengan batas-batas, hak-hak dan kedaulatan yang ditetapkan oleh undang-undang. Dalam kemajuan suatu negara terutama negara kepulauan seperti Indonesia alat transportasi merupakan suatu hal yang sangat penting untuk menjangkau setiap pulau atau daerah tersebut dengan cepat, hal ini tentu membutuhkan suatu perhatian dan peraturan dari pemerintah untuk mengatur sehingga penerbangan menjadi hal yang menyenangkan bagi semua penggunanya.olehnya pemerintah melalui Menteri Perhubungan No 89 Tahun 2015 tentang penanganan keterlambatan
\end{abstract}


penerbangan (Delay) pada Badan usaha angkutan udara Niaga berjadwal di Indonesia.

Kata Kunci :

Dampak, Regulasi, Maskpai Penerbangan

\section{A. PENDAHULUAN}

Penerbangan merupakan bagian dari system transportasi nasional dan internasional memiliki perkembangan dari segi teknologi dan kenyamanan serta mempunyai karakteristik mampu bergerak dalam waktu cepat dalam menghemat waktu, menggunakan teknologi tinggi, padat modal, manajemen yang andal, serta memerlukan jaminan keselamatan dalam bentuk asuransi dan penanganan yang efektif dan efisien sehingga menumbuhkan rasa aman dan nyaman bagi penggunanya.

Perkembangan dalam lingkungan strategis nasional dan internasional menuntut penyelenggaraan penerbangan yang sesuai dengan perkembangan ilmu pengetahuan dan teknologi, peran serta swasta dan persaingan usaha, perlindungan konsumen, ketentuan internasional yang disesuaikan dengan kepentingan nasional, akuntabilitas penyelenggaraan Negara, dan otonomi daerah.

Indonesia merupakan Negara dengan jumlah penduduk mencapai 257,9 juta jiwa dari 34 Provinsi dan 17.508 pulau dari sabang sampai Marauke yang tinggal di berbagai pulau sehingga membutuhkan alat transportasi pesawat terbang yang cukup tinggi untuk menjangkau ke beberapa daerah, hal ini memicu pemerintah pada masa pemerintahan Presiden Abdurrahman Wahid Tahun 2000 untuk membuka kesempatan yang sama ke berbagai maskapai untuk membuka penerbangan tidak hanya di dominasi oleh maskapai milik pemerintah atau BUMN tapi juga milik swasta sehingga banyak maskapai yang melayani rute penumpang.

Seiring dengan semakin murahnya tarif penerbangan di Indonesia, mengakibatkan jumlah penumpang yang lalu lalang melalui Bandara juga semakin bertambah, pertambahan ini tentunya juga mengakibatkan jumlah pengguna jasa dan maskapai dengan macam penawaran dan pasilitas dalam melayani penumpang.

Permasalahan keterlambatan keberangkatan (Delay) merupakan peristiwa yang sering terjadi dalam dunia penerbangan. Keterlambatan akibat cuaca buruk atau sebab force majeure masih bias di toleransi. Sebaliknya, keterlambatan akibat kelalaian maskapai adalah pelanggaran hak hak konsumen jasa penerbangan. Setelah adanya putusan perkara antara david Tobing melawan Lion Air pada Tahun 2008, yang menghukum masakapai untuk mengganti kerugian kepada konsumen Delay, Konsumen jasa penerbangan mulai di perhatikan. Pemerintah menerbitkan keputusan Menteri Perhubungan Nomor 89 Tahun 2015 tentang penanaganan keterlambatan penerbangan Delay pada Badan usaha angkutan udara niaga berjadwal di indonesia. Selain itu pemerintah juga mengeluarkan aturan tentang 
tanggung jawab pelaku usaha penerbangan kemudian diatur secara khusus melalui peraturan menteri perhubungan no 77/2011 tentang tanggung jawab pengangkut udara yang antara lain mengharuskan pihak maskapai mengganti atau bertanggung jawab kepada penumpang atas segala kehidupan atau kerusakan bagasi, pemberian ganti kerugian berupa uang akibat Delay lebih dari 4 jam, pembatalan penerbangan atau kecelakaan dalam penerbangan yang mengakibatkan kematian atau luka-luka. Pada Tahun 2012, Dalam peraturan Menteri Perhubungan No 89 Tahun 2015. Tentang Delay.

\section{Rumusan Masalah}

Bagaimana Tanggung Jawab hukum Maskapai Penerbangan Terhadap pelaksanaan Peraturan Menteri Perhubungan.

\section{Metode penelitian.}

\section{Lokasi Penelitian}

Adapun tempat penelitian ini yaitu Bandara Udara Internasional Sultan Hasanuddin Maros

\section{Populasi dan sampel}

a. Populasi

Populasi dalam penelitian ini adalah seluruh masalah penumpang delay yang pernah ada di Bandar Udara Sultan Hasanuddin Maros dari Tahun 2012-2015

b. Sampel

Sedangkan jumlah sampel yang ditetapkan adalah sebanyak 10 responden dari kasus yang pernah terdaftar di kantor Bandara Udara Sultan Hasanuddin Maros

\section{Jenis dan Sumber Data}

a. Jenis data.

Data kualitatif, yaitu data yang diperoleh dari kantor Bandara Udara Sultan Hasanuddin .

b. Data kualitatif, yaitu data yang diperoleh dalam bentuk tabel yang akan disajikan setelah penulis selesai melakukan penelitian.

c. Sumber data

a. Data primer, yaitu data yang bersumber dari hasil wawancara atau interview dengan para penggugat atau yang pernah bermasalah tentang masalah Delay Maskapai Penerbangan.

b. Data sekunder, yaitu data yang diperoleh dari kajian sejumlah dokumen tentang kasus penumpang dan peraturan Menteri Perhubungan serta literatur yang erat kaitannya dengan penelitian ini.

\section{Teknik pengumpulan data.}

Adapun teknik pengumpulan data yang dilakukan yaitu :

1. Penelitian kepustakaan (library research). 
Yaitu suatu metode penelitian yang dilakukan di perpustakaan dengan membaca buku-buku, literatur guna memperoleh, mengumpulkan data dan menilai data yang lebih akurat.

2. Penelitian lapangan (field research).

Yaitu penulis melakukan pengamatan langsung pada obyek penelitian, dengan cara:

a. Observasi, yakni dengan cara mengamati secara langsung objek penelitian kemudian mencatat data-data yang penting dan berkaitan dengan pembahasan ini.

b. Wawancara, dalam hal ini penulis akan mengadakan wawancara dengan yang pernah merasa di rugikan Oleh Maskapai Penerbangan

\section{Analisis Data.}

Data yang diperoleh di lapangan baik data primer maupun data sekuunder yang sifatnya kualitatif, akan dengan menggunakan teknik analisis deskriftif

\section{B. PEMBAHASAN}

\section{Pengertian Transportasi Udara}

Penerbangan adalah satu kesatuan system yang terdiri atas pemanfaatan wilayah udara, pesawat udara, Bandar udara, angkutan udara, navigasi penerbangan, keselamatan dan keamanan, lingkungan hidup, serta fasilitas penunjang dan fasilitas umum lainnya.

Pesawat udara adalah setiap mesin atau alat yang dapat terbang di atmosfer karena gaya angkat dari reaksi udara, tetapi bukan karena reaksi udara terhadap permukaan bumi yang digunakan untuk penerbangan

Pesawat terbang adalah pesawat udara yang lebih berat dari udara, bersayap tetap, dan dapat terbang dengan tenaga sendiri

Bandar udara internasional adalah Bandar udara yang ditetapkan sebagai Bandar udara yang melayani rute penerbangan dalam negeri dan rute penerbangan dengan dalam negeri dan rute penerbangan dari dan luar negeri

Transportasi udara adalah alat transportasi yang relatif lebih muda dibandingkan dengan transportasi darat dan laut, sehingga sering dijuluki sebagai the most regulated transportationyang diatur oleh berbagai ketentuan nasional (termasuk hukum udara) yang diserasikan dengan ketentuan-ketentuan internasional Salah satu tujuan diselenggarakannya penerbangan adalah mewujudkan penyelenggaraan penerbangan yang aman (safety, tertib dan teratur (Regularit ), nyaman (comfortable), dan ekonomis (economy for company)

Berawal dari tujuan tersebut terlihat dengan jelas bahwa sangat bertentangan dengan adanya peristiwa keterlambatan serta pembatalan penerbangan yang mencerminkan kurang disiplinnya pihak dari pelaku usaha transportasi. 
Terselenggaranya suatu pengangkutan udara dalam kegiatan penerbangan komersil tidak akan berarti apa - apa tanpa adanya penumpang.

Pada industri penerbangan, penumpang merupakan salah satu aset penting yang patut diperhitungkan bagi maskapai penerbangan untuk mencapai keuntungan. Oleh karena itu yang menggunakan jasa penerbangan perlu dilindungi haknya terutama hak ganti rugi apabila penumpang mengalami kecelakaan (yang menyebabkan kematian, luka luka, atau cacat tetap), kerusakan atau kehilangan bagasi, dan keterlambatan (Pasal 25 ayat (1) Ordonansi Pengangkutan Udara) Jika penumpang merasa kuantitas atau kualitas barang atau jasa yang dikonsumsinya

tidak sesuai dengan nilai tukar yang diberikannya, ia berhak mendapatkan ganti kerugian yang pantas. Berkaitan dengan itu sebagai salah satu ciri pelayanan umum adalah pemberi pelayanan bertanggung jawab dalam arti liability dalam hal penerima layanan mengalami kerugian akibat layanan yang diberikan

Terkait dengan keterlambatan penerbangan, Pasal 1 angka 30 Undang-Undang No. 1 Tahun 2009 Tentang Penerbangan (selanjutnya disingkat Undang-Undang Penerbangan) menjelaskan definisi keterlambatan sebagai “terjadinya perbedaan waktu antara waktu keberangkatan atau kedatangan yang dijadwalkan dengan realisasi waktu keberangkatan atau kedatangan".

Asas dan tujuan dalam penerbangan pasal 2

a. Manfaat

b. Usaha bersama dan kekeluargaan

c. Adil dan merata

d. Keseimbangan, keserasian, dan keselarasan

e. Kepentingan umum

f. Keterpaduan

g. Tegaknya hukum

h. Kemandirian

i. Keterbukaan dan anti monopoli

j. Berwawasan lingkungan hidup

k. Kedaulatan Negara

1. Kebangsaan dan

m. Kenusantaraan.

Penerbangan diselenggarakan dengan tujuan

a. Mewujudkan penyelenggaraan penerbangan yang tertib, teratur, selamat, aman, nyaman, dengan harga yang wajar, dan menghindari praktek persaingan usaha yang tidak sehat.

b. Memperlancar arus perpindahan orang/atau barang melalui udara dengan mengutamakan dan melindungi angkutan udara dalam rangka memperlancar kegiatan perekonomian nasional

c. Membina jiwa kedirgantaraan

d. Menjunjung kedaulatan Negara 
e. Menciptakan daya saing dengan mengembangkan teknologi dan industry angkutan udara nasional

f. Menjunjung menggerakkan dan mendorong pencapaian tujuan pembangunan nasioanl

g. Mmeperkukuh kesatuan dan persatuan bangsa dlaam rangka perwujudan wawasan nusantara

h. Meningkatkan ketahanan nasional

i. Mempererat hubungan antar bangsa.

Kenyataannya, transportasi udara tidak selamanya mendatangkan berbagai keuntungan bagi masyarakat terutama yang sangat penting adalah waktu. Transportasi udara memang dapat dengan cepat menghubungkan satu tujuan ke tujuan lainnya, namun di luar itu sering kali transportasi udara ini menimbulkan kerugian bagi penumpang, di mana maskapai terkadang tidak memenuhi apa yang sudah menjadi kewajibannya atau dengan kata lain wanprestasi.

Apabila penumpang yang menggunakan jasa penerbangan berakibat terjadinya pelanggaran hak-hak penumpang yang menimbulkan kerugian, maka pengangkut bertanggung jawab seperti yang diamanatkan oleh Undang-Undang Penerbangan. Tanggung jawab dimulai sebelum masa penerbangan (pre-flight service), pada saat penerbangan (inflight service), dan setelah penerbangan (postflight service)

Kerugian sebelum masa penerbangan misalnya berkaitan dengan pembelian tiket, penyerahan bagasi, penempatan bagasi pada rute yang salah atau terjadi keterlambatan. Kerugian pada saat penerbangan misalnya tidak mendapatkan pelayanan yang baik atau rasa aman untuk sampai di tujuan dengan selamat. Sedangkan kerugian setelah penerbangan, antara lain sampai di tujuan terlambat, bagasi hilang atau rusak.

Keterlambatan penerbangan yang dilakukan oleh pihak penyedia jasa penerbangan merupakan suatu pelanggaran, karena tidak terlaksananya suatu perjanjian pengangkutan dengan baik sesuai dengan yang telah disepakati sebelumnya. Pelanggaran atau tidak dilaksanakannya suatu perjanjian pengangkutan dapat timbul dalam hal sebagai berikut

1. Adanya penolakan secara tidak sah oleh pengangkut untuk melaksaakan perjajian pengangkutan

2. Hanya sebagian dari pengangkutan itu yang dilaksanakan.

3. Adanya keterlambatan di pihak pengangkut dengan akibat bahwa sasaran dari pelaksanaan usaha tersebut menjadi terhalang atau tidak Tanggung Jawab Maskapai Penerbangan Sebagai Penyedia Jasa Penerbangan Kepada Penumpang Akibat Keterlambatan Penerbangan dapat dilaksanakan sesuai dengan yang seharusnya dan para penumpang dibenarkan menyatakan bahwa perjanjian tersebut batalKerugian yang dialami oleh penumpang tidak hanya kerugian materil melainkan juga kerugian immateril. Tidak mudah memang menuntut tanggung gugat sebuah maskapai penerbangan, namun yang terpenting adalah 
bagaimana peran pemerintah dalam membentuk suatu aturan untuk menentukan tanggung gugat para pihak khususnya pada pihak pengangkut jika dalam perusahaan penerbangan ada permasalahan Fokus penelitian ini adalah menyangkut keterlambatan penerbangan, ditinjau dari Undang-Undang Penerbangan dan Peraturan Menteri Perhubungan.

\section{Ganti Rugi Dalam Hukum Perlindungan Konsumen}

Pelaku usaha bertanggung jawab memberikan ganti rugi atas kerusakan, pencemaran, dan/atau kerugian konsumen akibat mengkonsumsi barang dan/atau jasa yang dihasilkan atau diperdagangkan. Jika konsumen pemanfaat jasa multimedia dirugikan akibat mengkonsumsi jasa yang diperdagangkan oleh penyelenggaraan jasa multimedia, konsumen dapat meminta ganti rugi atas kerugian yang dideritanya tersebut.

Ganti rugi dapat berupa pengembalian uang atau penggantian barang dan/atau jasa yang sejenis atau setara nilainya, atau perawatan kesehatan dan/atau pemberian santunan yang sesuai dengan ketentuan peraturan perundang-undangan yang berlaku.

Pemberian ganti rugi dilaksanakan dalam tenggang waktu 7 (tujuh) hari setelah tanggal transaksi dan pemberian ganti rugi tersebut tidak menghapuskan kemungkinan adanya tuntutan pidana berdasarkan pembuktian lebih lanjut mengenai adanya unsur kesalahan.

Jika pelaku usaha menolak dan/atau tidak memberikan tanggapan dan/atau tidak memenuhi ganti rugi atas tuntutan konsumen, maka pelaku usaha tersebut dapat digugat melalui badan penyelesaian sengketa konsumen atau diajukan ke badan pengadilan di tempat kedudukan konsumen. Pembuktian terhadap ada tidaknya unsur kesalahan dalam gugatan ganti rugi merupakan beban dan tanggung jawab pelaku usaha.

\section{Tanggung Jawab Maskapai Pada Pihak penumpang Yang mengalami delay.}

Keterlambatan penerbangan dihitung berdasarkan perbedaan waktu antara waktu keberangkatan atau kedatangan yang dijadwalkan, dengan realisasi waktu keberangkatan atau kedatangan yaitu pada saat pesawat Block off meninggalkan tempat parkir pesawat Block-on dan parkir di apron Bandara tujuan.

Dasar hukum dalam penerbangan yang mengalami delay

a. Undang-Undang Nomor 8 tahun 1999 tentang perlindungan konsumen

b. Undang-Undang Nomor 1 Tahun 2009 tentang penerbangan

c. Undang-Undang Nomor 25 Tahun 2009 tentang pelayanan publik

d. Peraturan presiden Nomor 24 Tahun 2009 tentang kedudukan tugas dan

e. Peraturan Menteri Perhubungan No 89 tahun 2015 tentang penangan keterlambatan penerbangan pada Bandan usaha angkutan udara fungsi kementerian Negara serta susunan organisasi tugas dan fungsi eselon 1 
kememterian Negara sebagaimana diubah terakhir dengan peraturan preseden no 235 tahun 2004.

f. Peraturan Presiden Nomor 7 tahun 2015 tentang organisasi kementerian Negara.

Kategori keterlambatan beserta kompensasinya dan ganti rugi. Ada dua yaitu

a. Keterlambatan pada kategori 2 sampai dengan 5 penumpang dapat dialihkan ke penerbangan berikutnya atau mengembalikan seluruh biaya tiket.

b. Keterlambatan diatas 6 jam, apabila dibutuhkan penumpang wajib diberikan kompensasi berupa tempat penginapan dan akomodasi bagi penumpang.

Sebelum menguraikan lebih lanjut mengenai konvensi warsawa 1929 beserta protokol dan suplemennya, protokol Tambahan montreal 1975 No 1,2,3, maupun konvensi Montreal 1999 lebih dahulu perlu dijelaskan konsep tanggung jawab hukum dalam hukum perdata internasional, tanggung jawab hukum perusahaan penerbangan yang digunakan dalam hukum udara. Dalam hukum udara perdata internasional maupun nasional terdapat beberapa konsep tanggung jawab perusahaan penerbangan terhadap penumpang, pengirim barang maupun pihak ketiga.

Sebagaimana disebutkan diatas, menurut ajaran hukum yang berlaku di Common Law system maupun Continental Law system, perusahaan penerbangan sebagai pengangkut yang menyediakan jasa transportasi udara untuk umum bertanggung jawab atas kerugian yang diderita oleh penumpang atau pengirim barang.

Menurut aturan hukum terjadi suatu perubahan pergeseran tanggung jawab dari korban kepada pelaku pengangkutan karena, dari korban kepada pelaku pengangkutan, karena itu perusahaan penerbangan secara yuridis bertanggung jawab terhadap penumpang dan atau pengirim barang. Di samping itu, perusahaan penerbangan yang menyediakan pengangkutan umum tidak hanya bertanggung jawab atas perbuatannya sendiri, tetapi juga harus bertanggung jawab atas perbuatan karyawan, pegawai, agen atau perwakilannya atau orang yang bertindak untuk dan atas nama perusahaan penerbangan tersebut.

Menurut ajaran hukum tersebut, untuk keperluan tanggung jawab majikan dengan karyawan, pegawai, atau agen atau perwakilannya atau orang yang bertindak untuk dan atas nama perusahaan penerbangan tersebut dianggap seorang, karena itu berdasarkan ajaran hukum tersebut, perusahaan penerbangan harus bertanggung jawab terhadap penumpang, pengirim barang maupun pihak ketiga. Walaupun yang melakukan karyawan, pegawai, atau agen atau perwakilannya atau orang yang bertindak untuk dan atas nama perusahaan penerbangan. Dalam pengangkutan udara terdapat 


\section{PEMBAHASAN}

\section{Tanggung Jawab Hukum Maskapai Penerbangan Terhadap Pelaksanaan Peraturan Delay N0 89 Tahun 2015.}

Dalam pengangkutan udara terdapat 3 macam konsep dasar tanggung jawab hukum masing-masing konsep tanggung jawab atas dasar kesalahan, konsep tanggung jawab hukum atas kesalahan, konsep tanggung jawab hukum atas praduga tak bersalah dan tanggung jawab hukum tanpa bersalah atau tanggung jawab mutlak.

a. Tanggung jawab hukum atas dasar kesalahan. Tanggung jawab ini ada dalam pasal 1365 kitab undang-undang Hukum Perdata. Pasal tersebut yang dikenal sebagai tindakan melawan hukum (onrechtsmatigdaad) berlaku umum terhadap siapa pun juga, termasuk perusahaan penerbangan. Menurut pasal tersebut setiap perbuatan melawan hukum yang menimbulkan kerugian terhadap orang lain mewajibkan orang yang karena perbuatannya menimbulkan kerugian itu mengganti kerugian berdasarkan ketentuan tersebut setiap orang harus bertanggung jawab secara hukum atas perbuatan sendiri artinya apabila karena perbuatannya mengakibatkan kerugian kepada orang lain, maka orang tersebut harus bertanggung jawab untuk membayar ganti rugi yang diderita oleh orang tersebut. Menurut pasal 1367 kitab undang-undang Hukum Perdata, tanggung jawab hukum kepada orang yang menderita kerugian tidak hanya terbatas kepada perbuatan sendiri, melainkan juga terhadap perbuatan, karyawan, pegawai, agen, perwakilannya apabila menimbulkan kerugian kepada orang lain, sepanjang orang tersebut bertindak sesuai dengan tugas dan kewajiban yang dibebankan kepada orang tersebut. Tanggung jawab semacam ini juga dikenal dalam comman law system dalam tanggung jawab atas kesalahan harus memenuhi unsure-unsur adanya kesalahan ada kerugian dan kerugian tersebut ada hubungannya dengan kesalahan. Korban yang harus membuktkan adanya kesalahan, bilamana terbukti ada kesalahan jumlah ganti rugi tidak terbatas, korban sebagai penggugat dengan perusahaan sebagai tergugat mempunyai kedudukan yang sama dalam arti dapat saling membuktikan.

b. Tanggung jawab praduga bersalah sebagaimana di muka, dalam perkembangannya tanggung jawab atas dasar kesalahan tidak dapat diterapkan dalam pengangkutan udara, karena kedudukan antara penumpang dan atau pengirim barang dengan perusahaan penerbnagan tidak seimbang. Dalam pengangkutan udara, khususnya perusahhaan penerbangan menguasai teknologi tinggi, sementara itu penumpang dan atau pengirim barang tidak menguasai teknologi tinggi penerbangan, sehingga apabila penumpang dan atau pengirim barang harus membuktikan kesalahan perusahaan penerbangan pasti tidak akan berhasil, karena itu sejak tahun 1929 dikenakan konsep tanggung jawab hukum. Konsep tanggung jawab hukum atas dasar praduga bersalah mulai diterapkan sejak konvensi warsawa 1929. Menurut konsep tanggung 
jawab hukum praduga bersalah, perusahaan penerbangan dianggap bersalah, sehingga perusahaan penerbangan demi hukum harus membayar ganti kerugian yang diderita oleh penumpang dan atau pengirim barang tanpa dibuktikan kesalahan lebih dahulu, kecuali perusahaan penerbangan membuktikan kesalahan perusahaan penerbangan, cukup member tahu adanya kerugian yang terjadi pada saat kecelakaan. Sehingga penumpang dan atau pengirim barang tidak harus membuktikan kesalahan perusahaan penerbangan. Sebagai imbalan, perusahaan penerbangan berhak menikmati batas maksimum ganti rugi yang ditetapkan dalam konvensi atau regulasi artinya berapa pun juga kerugian yang diderita oleh penumpang dan atau pengirim barang. Unsure -unsur penerbangan tidak akan bertanggung jawab membayar semua kerugian yang diderita oleh penumpang dan atau pengirim barang. konsep tanggung jawab praduga bersalah

c. Tanggung jawab terbatas, sebagai konsekunsi konsep tanggung jawab hukum praduga bersalah, maka perusahaan penerbangan demi hukum bertanggung jawab, tanpa dibuktikan lebih dahulu secara hukum terhadap kerugian yang diderita oleh penumpang dan atau pengirim barang, namun demikian tanggung jawab perusahaan penerbangan terbatas sebesar jumlah kerugian yang ditetapkan dalam konvensi internasional atau peraturan perundang-undnagan nasioanl yang berlaku.untuk setiap penumpang yang meninggal dunia atau luka tetap atau semenatara atau barang hilang, musnah, dan atau tidak dapat digunakan sebagian maupun seluruhnya. Berapa pun juga kerugian yang diderita oleh penumpang tidak akan memperoleh ganti rugi seluruhnya.

\section{KESIMPULAN}

1. Tanggung Jawab Maskapai Penerbangan terhadap pelaksanaan peraturan menteri perhubungan. memperbaiki pelayanan dan pemahaman kepada penumpang pengguna pesawat dengan memberikan tanggung jawab secara penuh, mengganti kerugian serta memperbaiki pelayanan dangan maksimal dan efisien.

2. Saran. Dapat menambah pengetahuan kepada masyarakat khususnya kepada masyarakat pengguna pesawat terbang, terutama bidang hukum perlindungan konsumen serta pemahaman kepada penulis sendiri. 


\section{Daftar Pustaka}

Achmad Ali, Menguak Tabir Hukum, PT, Gunung Agung, Jakarta. 2002

--------------, Menguak Realitas Hukum, Kencana Media, Jakarta. 2002

Martono, Hukum Udara Nasional dan Internasioanl, Raja grafindo, Jakarta, 2012.

Martono, Hukum Udara Perdata, Raja Grafindo, Jakarta. 2013.

Marhaeni Rio siombo, Hukum lingkungan dan pelaksanaanya pembangunan berkelanjutan di Indonesia, Kompas, Jakarta. 2012.

Munir Fuady, Konsep Negara Demokrasi, Aditama, Bandung. 2012

Luhut Pangaribuan, Hukum Acara Pidana, Djambatan, Jakarta. 2003

Philippe Nonet, Hukum Responsif, Nusamedia, Bandung. 2010

Satjipto Raharjo,2009, Penegakan Hukum, Genta Publising, Jakarta.

------, Sisi Sisi lain Dari Hukum, Kompas, Jakarta. 2009

Undang-Undang Nomor 8 Tahun 1999, Tentang perlindungan konsumen.

Undang-Undang Nomor 1 Tahun 2009 tentang penerbangan.

Undang-Undang Nomor 25 Tahun 2009 tentang pelayanan publik.

Peraturan presiden Nomor 24 Tahun 2009 tentang kedudukan tugas dan Peraturan Menteri Perhubungan No 89 Tahun 2015 tentang penangan keterlambatan penerbangan pada Bandan usaha angkutan udara, Bandung. Panduan Bantuan Hukum, 2006 YLBHI 